\title{
REDISCOVERY OF MERISTASPIS LATERALIS (KOLENATI) (ACARI: MESOSTIGMATA: SPINTURNICIDAE) PARASITIZING THE EGYPTIAN FRUIT BAT, ROUSETTUS AEGYPTIACUS (GEOFFROY) (MAMMALIA: CHIROPTERA), WITH A KEY TO MITES OF BATS IN EGYPT
}

By

MOHAMED W. NEGM and MAHMOUD M. FAKEER

Department of Plant Protection, Faculty of Agriculture, Assiut University, Assiut 71526, Egypt. Correspondence: Dr. Mohamed W. Negm, email: waleednegm@yahoo.com

\begin{abstract}
Faunistic information about bat mites in Egypt is scarce. Collection records of parasitic mites, Meristaspis lateralis (Kolenati, 1856) (Mesostigmata: Spinturnicidae), are reported from the Egyptian fruit bat, Rousettus aegyptiacus (Geoffroy, 1810) (Mammalia: Chiroptera) in Assiut Governorate, Egypt. Seven species of bat mites are recognized from Egypt to date. A hostparasite checklist and an identification key to these species are presented.
\end{abstract}

Key words: Acari, mites, key, bats, Chiroptera, Egypt

\section{Introduction}

The Egyptian fruit bats, Rousettus aegyptiacus (Geoffroy, 1810) (Mammalia: Chiroptera) are widely distributed frugivores, prefer feeding on ripe tissues and juices of fruits of different crops. Because of consuming large amounts of fruit, about 50 to $150 \%$ of total body mass each night, $R$. aegyptiacus is considered a hazard to crops during growing season (Fujita and Tuttle, 1991; Kwiecinski and Griffiths, 1999).

Bats can be infested with various mite groups. Mites of the family Spinturnicidae and many species of Macronyssidae are exclusive parasites of bats during their all life stages (Krantz and Walter, 2009). They feed as obligate ecto-parasites on the blood or lymph of their hosts (Baker and Craven, 2003). Rudnick (1960) and Radovsky (1967) provided taxonomic reviews about mites of families Spinturnicidae and Macronyssidae, respectively.

This paper presents a host-parasite checklist and a key to mite species collected from bats in Egypt to date, on which to build further information of this fauna.

\section{Materials and Methods}

The Egyptian fruit bat, $R$. aegyptiacus
(Geoffroy, 1810) (Mammalia: Chiroptera) was observed at night hanging on a tree of white mulberry, Morus alba L. (Moraceae) and was collected by shooting. Mites were collected by visual examination under a stereoscopic microscope (VisionScope 2, ken$a$-vision ${ }^{\circledR}$, USA) from the internal side of wing membranes and sporadically the tail membrane with the help of a fine brush. The mite specimens were cleared in lactic acid, mounted in Hoyer's medium, dried on a hot plate, ringed with nail polish and studied under a research microscope $(\mathrm{CxL}$, Labomed $^{\circledR}$, USA). The voucher slide-mounted samples were deposited in the Acarology Museum, Plant Protection Department, Faculty of Agriculture, Assiut University, Egypt.

\section{Results}

Seven species of Mesostigmata, classified in two families and four genera, are reported from bats in Egypt to date (Table 1).

The collection records (nine females and six males) of Meristaspis lateralis (Kolenati,

1856) (Mesostigmata: Spinturnicidae) are rediscovered parasitizing $R$. aegyptiacus in the agricultural farm of Assiut University, Assiut Governorate, Egypt. 
Table 1: Checklist of mite species so far reported from bats in Egypt.

\begin{tabular}{|c|c|c|c|c|}
\hline Family & Species & Host & Host family & Reference \\
\hline \multirow[t]{2}{*}{$\begin{array}{l}\text { Macrony- } \\
\text { ssidae }\end{array}$} & $\begin{array}{l}\text { Steatonyssus longipes } \\
\text { Radovsky and Yunker }\end{array}$ & $\begin{array}{l}\text { Nycteris thebaica } \\
\text { Geoffroy }\end{array}$ & Nycteridae & $\begin{array}{l}\text { Radovsky and } \\
\text { Yunker, } 1963\end{array}$ \\
\hline & S. murinus (Lucas)* & Pipistrellus kuhlii & Vespertilionidae & Keegan, 1956 \\
\hline \multirow[t]{6}{*}{$\begin{array}{l}\text { Spinturn- } \\
\text { icidae }\end{array}$} & $\begin{array}{l}\text { Ancystropus aethiopicus } \\
\text { Hirst }\end{array}$ & $\begin{array}{l}\text { Rousettus aegyptiacus } \\
\text { (Geoffroy) }\end{array}$ & Pteropodidae & Hafez et al., 1994 \\
\hline & A. zeleborii Kolenati & $\begin{array}{l}\text { Rhinopoma } \\
\text { microphyllum }\end{array}$ & Rhinopomatidae & Kolenati, 1856 \\
\hline & & Ro. aegyptiacus & Pteropodidae & $\begin{array}{l}\text { Kolenati, } 1856, \\
1860\end{array}$ \\
\hline & $\begin{array}{l}\text { Meristaspis kenyaensis } \\
\text { (Radford) }\end{array}$ & Ro. aegyptiacus & Pteropodidae & Hafez et al., 1994 \\
\hline & M. lateralis (Kolenati) & Ro. aegyptiacus & Pteropodidae & $\begin{array}{l}\text { Kolenati, 1856; } \\
\text { present study }\end{array}$ \\
\hline & $\begin{array}{l}\text { Paraperiglischrus } \\
\text { rhinolophinus (C.L. Koch) }\end{array}$ & $\begin{array}{l}\text { Rhinolophus clivosus } \\
\text { Cretzschmar }\end{array}$ & Rhinolophidae & Kolenati, 1859 \\
\hline
\end{tabular}

\section{Discussion}

Bats (Chiroptera) are the most abundant species of mammals and have a worldwide distribution. They inhabit a wide range of ecosystems and are known for their ecological importance as seed dispersers, pollinators and insectivores.

In Egypt, the mite fauna reported in the association with bats is very limited. Only seven species, classified in two families and four genera, were reported. Hafez et al. (1994) reported four species of the Spinturnicidae collected from bats in Qualyoubia Governorate, two of which, Ancystropus aethiopicus Hirst, 1923 and Meristaspis kenyaensis (Radford, 1947), were considered as new records.

On the other hand, Egyptian bats were incriminated to have a zoonotic role in leishmaniasis as antibodies were detected in seven bats (Morsy et al., 1987b). Besides, Trypanosoma vespertilionis (Battaglia, 1904) was reported from Egyptian bats (Morsy et al., 1986), and bat bug Cimex pipistrelli from bat roosts was the vector of Schizotrypanum $T$. (S.) dionisii and $T$. (S.) vespertilionis in British bats (Gardner and Molyneux, 1988). Nycteria medusiformis Garnham and Heisch, 1953 is a malaria parasite of the Egyptian insectivorous bat, Taphozous perforatus (Morsy et al., 1987a). Korine et al. (2012) detected Xenopsylla ramesis, a plague vector flea on frugivorous Egyptian fruit bat (Rousettus aegyptiacus). Also, $R$. aegyptiacus, is currently considered as a potential reservoir host for Marburg hemorrhagic virus (Paweska et al, 2012). Nakamura et al. (2013) described an outbreak of yersiniosis in $R$. aegyptiacus caused by Yersinia pseudotuberculosis serotype $4 b$.

\section{Conclusion}

The outcome results showed that the Egyptian fruit bats were infested with seven species of mites. Besides, the detection of zoonotic parasites increased their importance as reservoir hosts. Bats and their parasites are increasingly investigated for their role in maintenance and transmission of the potentially emerging pathogens. This must be in consideration of the Egyptian Scientific Authorities.

\section{Acknowledgment}

The authors would like to thank Amr Gnaidy and Mohammed A. Negm for hunting bats. For the authorization to use figures, the authors also acknowledge Dr. G.W. Krantz, Oregon State University, Oregon, USA, and the University of California Press.

\section{References}

Baker, AS, Craven, JC, 2003: Checklist of the mites (Arachnida: Acari) associated with 
bats (Mammalia: Chiroptera) in the British Isles. Syst. Appl. Acarol. Spec. Publ. 14:120.

Fujita, M, Tuttle, M, 1991: Flying foxes (Chiroptera: Pteropodidae): Threatened animals of key ecological and economic importance. Conserv. Biol. 5:455-63.

Gardner, RA, Molyneux, DH, 1988: Schizotrypanum in British bats. Parasitol. 97, 1: 43-50.

Hafez, SM, Ebaid, NM, Tharwat, ME, Abdel-Megeed, AE, 1994: Bat mites of Egypt (Acari: Spinturnicidae). Ann. Agric. Sci. Ain Shams University, Cairo 39, 1:463-71.

Hirst, S, 1923: On some new or littleknown species of Acari. Proc. Zool. Soc. London 971-1000.

Keegan, HL, 1956: Ectoparasitic laelaptid and dermanyssid mites of Egypt, Kenya and the Sudan, primarily based on NAMRU-3 collections, 1948-1953. J. Egypt. Publ. Hlth. Assoc. 31, 6:199-272.

Koch, CL, 1841: Deutschlands Crustaceen, Myriapoden und Arachniden. 37, Friedrich Pustet. Regensburg.

Kolenati, FA, 1856: Die Parasiten der Chiroptern. Brünn: Rudolph Rohrers Erben.

Kolenati, FA, 1859: Beiträge zur Kentniss der Arachniden. Sitzungsb. K. Akad. Wissensch. Wien, Math. Natur. CL. 35:155-90.

Kolenati, FA, 1860: Beiträge zur Kentniss der Arachniden. Sitzungsb. K. Akad. Wissensch. Wien, Math. Natur. CL. 40, 2:573-81.

Korine, C, Krasnov, BR, Khokhlova, IS, Pinshow, B, 2012: Effects of host diet and thermal state on feeding performance of the flea Xenopsylla ramesis. J. Exp. Biol. 215, 9: 1435-41.

Krantz, GW, 1978: A Manual of Acarology; Oregon State University Book Store, USA.

Krantz, GW, Walter, DE, 2009: A Manual of Acarology. Third Edition; Texas Technical University Press, Lubbock, Texas, USA.

Kwiecinski, G, Griffiths, T, 1999: Rousettus aegyptiacus. Mamm. Species, 611:1-9.

Morsy, TA, Khalid, ML, Bebars, MA, Abdel-Hamid, MY, 1986: Trypanosoma vespertilionis (Battaglia, 1904) from Egyptian bats. J. Egypt. Soc. Parasitol. 16, 2:373-7. Morsy, TA, Khaled, ML, Bebars, MA, Ramadan, NF, Abdel Hamid, MY, 1987a: Nycteria medusiformis Garnham and Heisch, 1953: a malaria parasite of the Egyptian insectivorous bat, Taphozous perforatus. J. Egypt. Soc. Parasitol.17, 1:1-7.

Morsy, TA, Salama, MM, Abdel Hamid, MY, 1987b: Detection of Leishmania antibodies in bats. J. Egypt. Soc. Parasitol. 17, 2:797-8.

Nakamura, S, Settai, S, Hayashidani, H, Urabe, T, Namai, S, et al., 2013: Outbreak of yersiniosis in Egyptian rousette bats (Rousettus aegyptiacus) caused by Yersinia pseudotuberculosis serotype 4b. J. Comp. Pathol. 148, 4:410-3.

Oudemans, AC, 1902: Notes on Acari, sixth series. Tijdschr. Entomol. 46:1-24.

Oudemans, AC, 1936: Kritisch historisch overzicht der acarologie (Critico-historical survey of acarology). Derde gedeelte 18051850. Band A. Leiden: K J. Brill.

Paweska, JT, van Vuren, PJ, Masumu, J, Leman, PA, Grobbelaar, AA, et al., 2012: Virological and serological findings in Rousettus aegyptiacus experimentally inoculated with vero cells-adapted hogan strain of Marburg virus. PLoSOne. 7(9):e45479. doi: 10. 1371/journal.pone.0045479.

Radford, CD, 1947: Two new bat mites of the genus Ancystropus (Acarina: Spinturnicidae). Proc. Zool. Soc. London 117:305-12.

Radovsky, FJ, 1967: The Macronyssidae and Laelapidae (Acarina: Mesostigmata) parasitic on bats. University of California Publications in Entomology 46:1-288.

Radovsky, FJ, Yunker, CE, 1963: Four new species of Steatonyssus from Africa (Acarina: Dermanyssidae). J. Parasitol. 49, 2:334-9.

Rudnick, A, 1960: A revision of the mites of the family Spinturnicidae (Acarina). University of California Publications in Entomology 17, 2:157-248.

Till, WM, Evans, GO, 1964: The genus Steatonyssus Kolenati (Acari: Mesostigmata). Bulletin of the British Museum, Natural History, Zool. 11:511-82. 


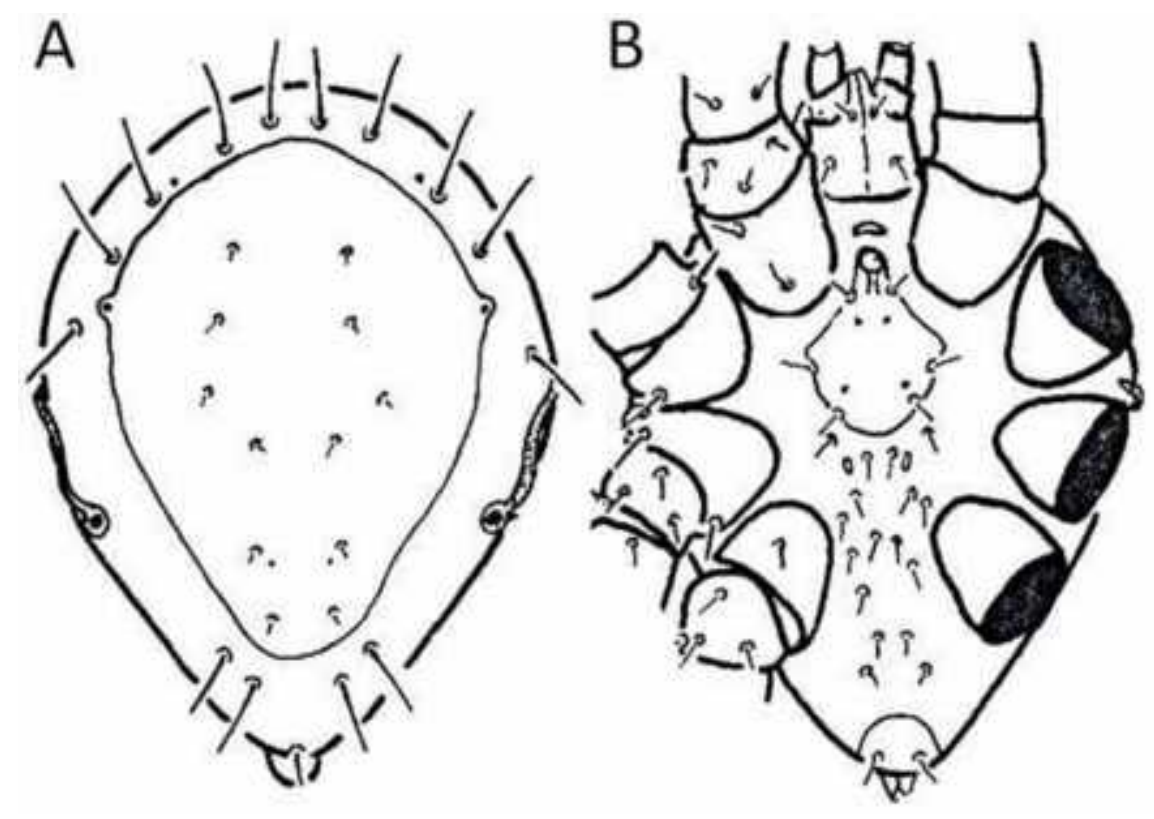

Figure 1: Family Spinturnicidae Oudemans, 1902. A, male dorsum, B, male venter (Krantz, 1978)

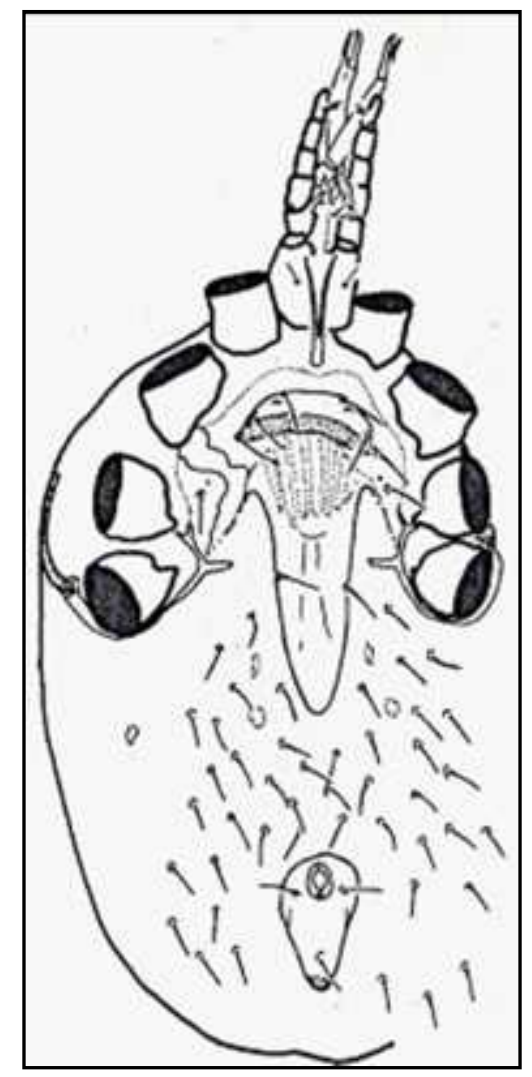

Figure 2: Family Macronyssidae Oudemans, 1936. Female venter (Krantz, 1978) 

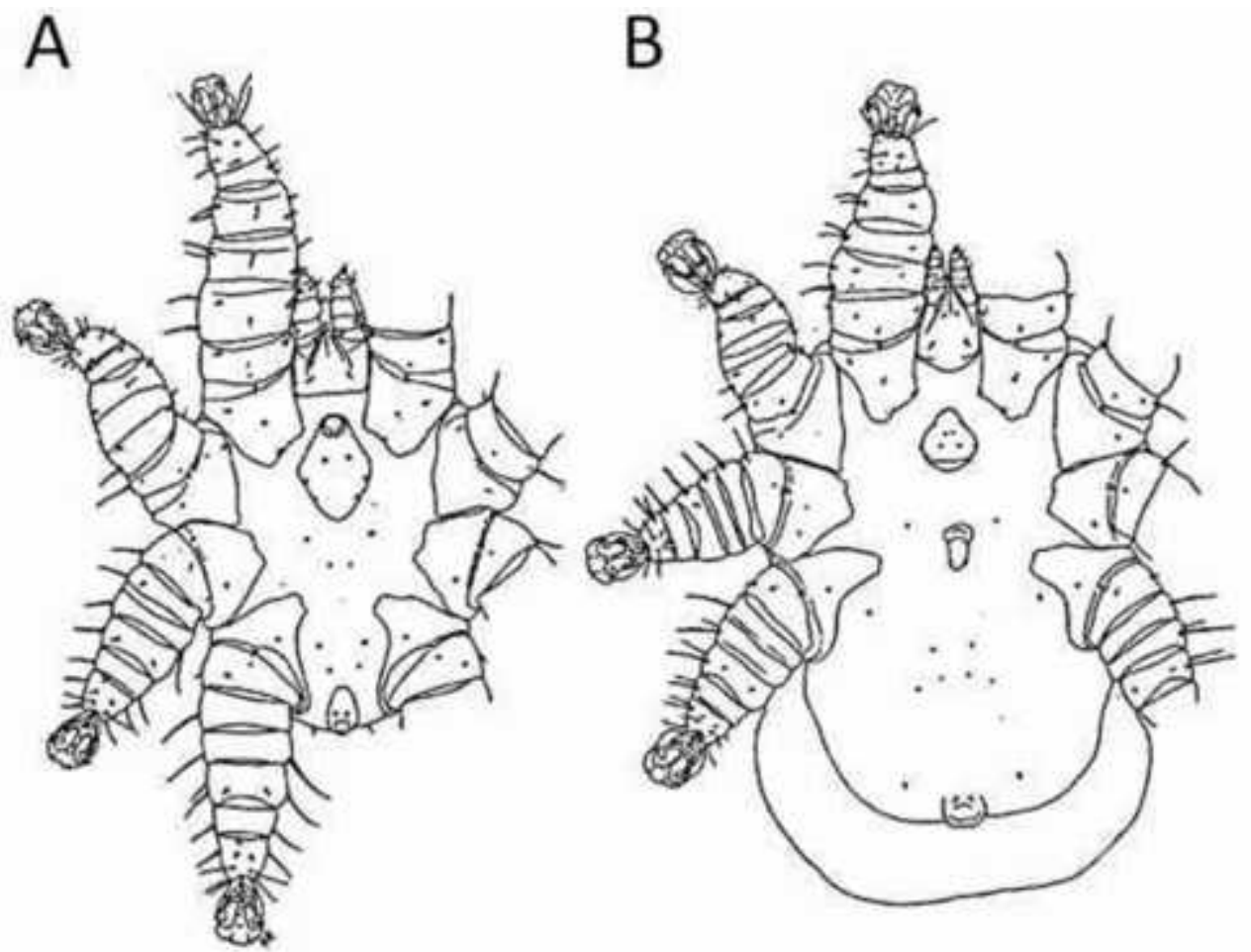

Figure 3: Paraperiglischrus rhinolophinus (C.L. Koch, 1841). A, male venter, B, female venter (Rudnick, 1960)
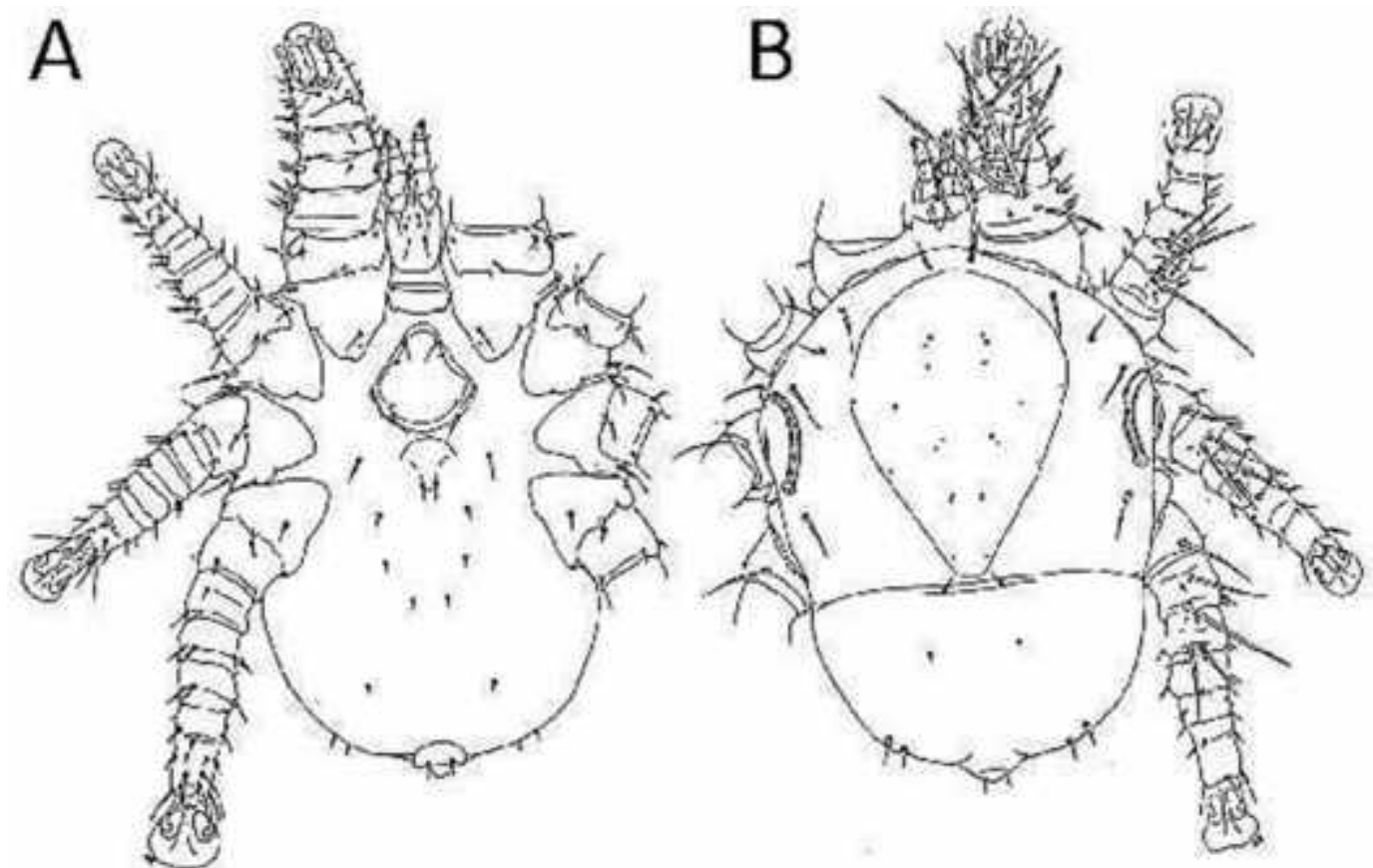

Figure 4: Meristaspis lateralis (Kolenati, 1856). A, female venter, B, female dorsum (Rudnick, 1960) 

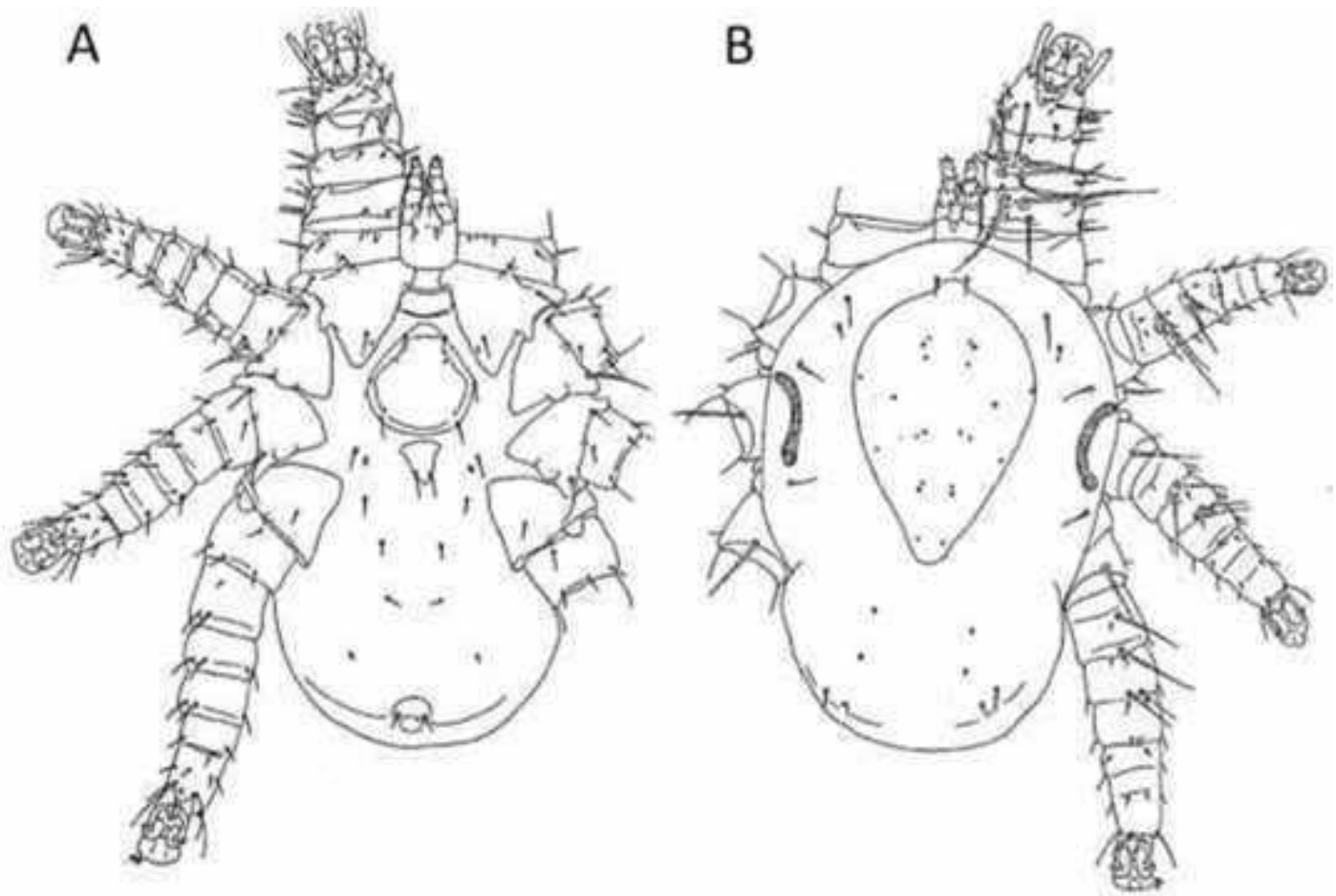

Figure 5: Meristaspis kenyaensis (Radford, 1947). A, female venter, B, female dorsum (Rudnick, 1960)

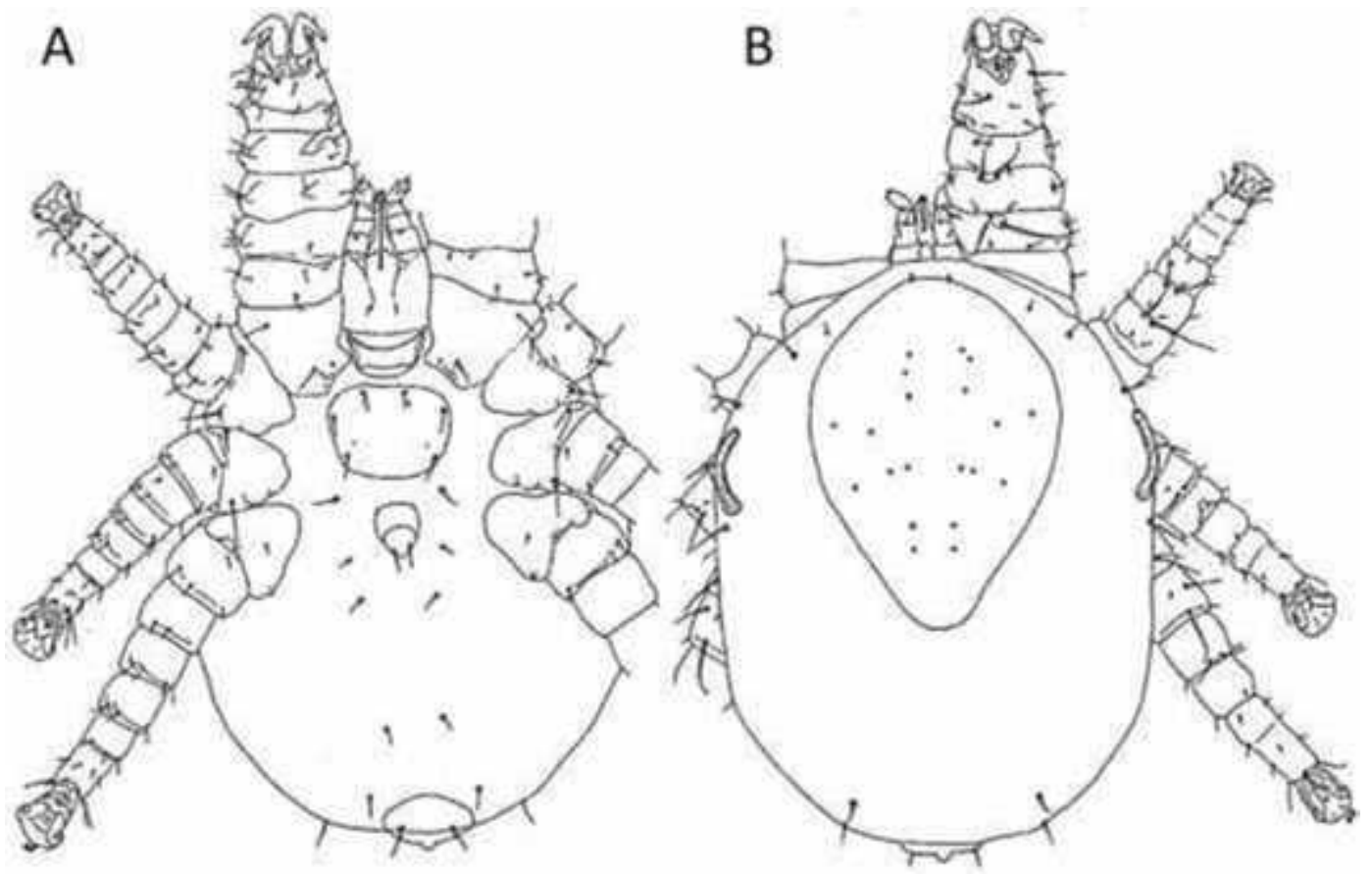

Figure 6: Ancystropus aethiopicus Hirst, 1923. A, female venter, B, female dorsum (Rudnick, 1960) 


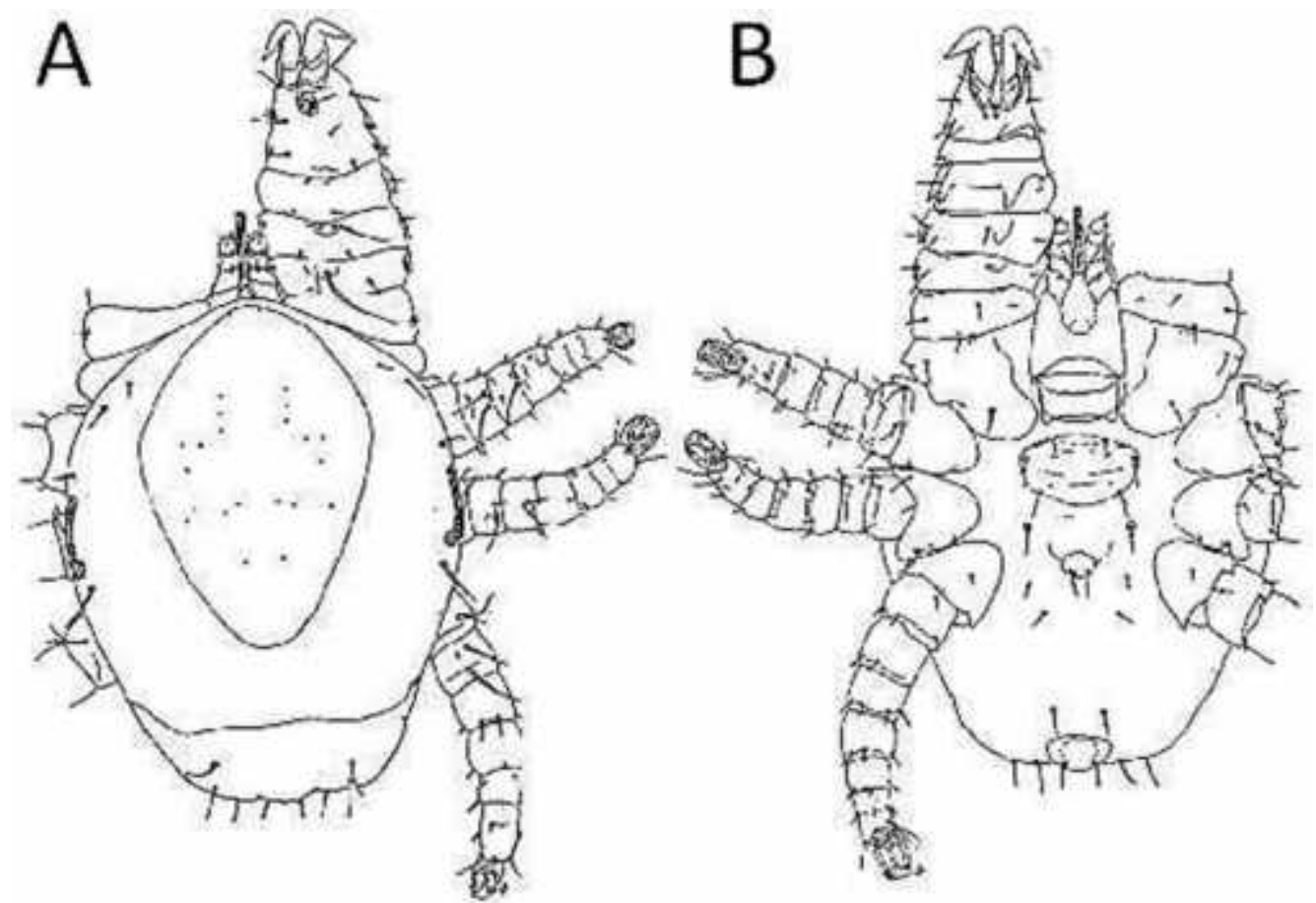

Figure 7: Ancystropus zeleborii Kolenati, 1856. A, female dorsum, B, female venter (Rudnick, 1960)

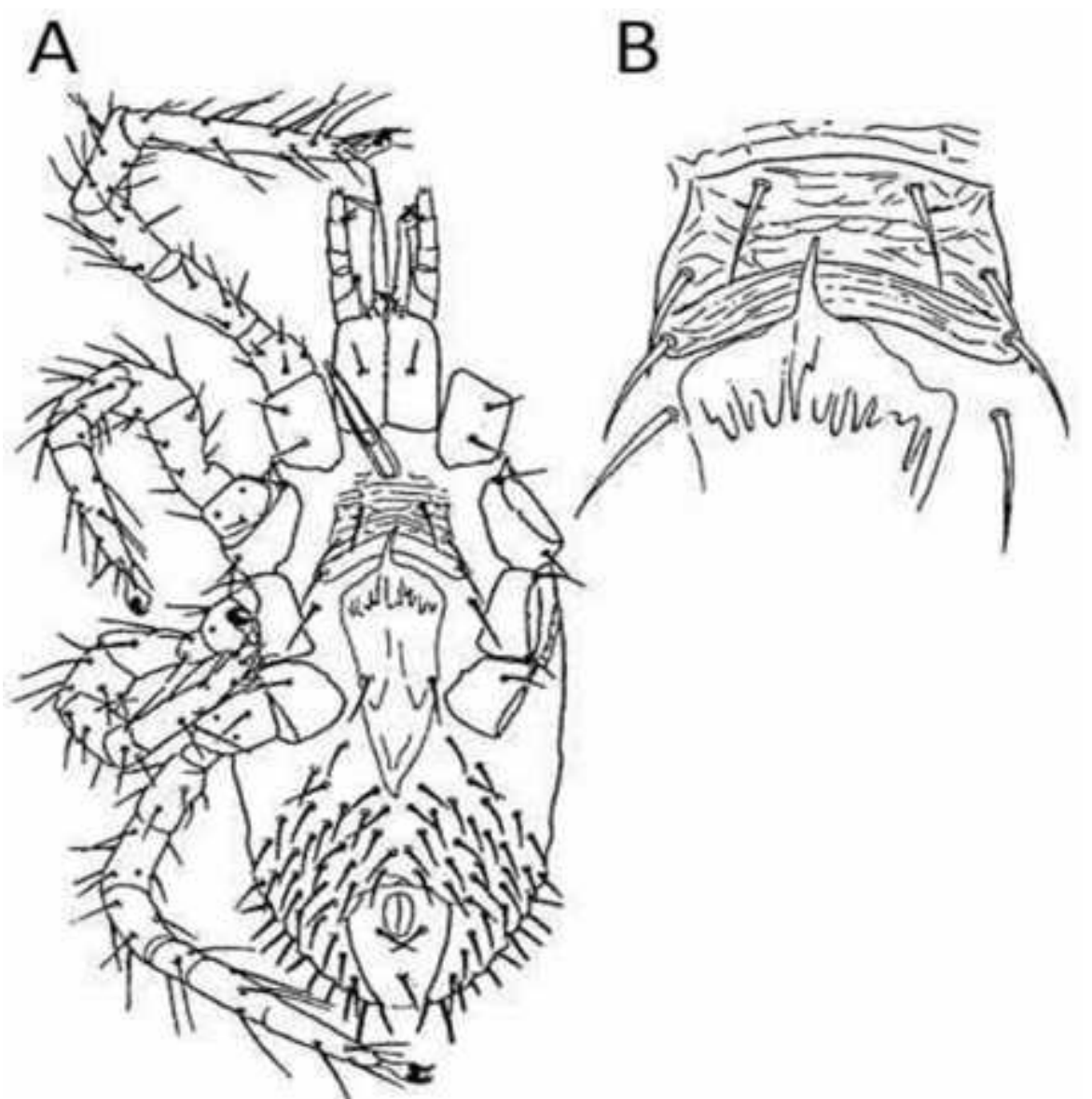

Figure 8: Steatonyssus longipes Radovsky and Yunker, 1963. A, female venter, B, sternal shield of female (Radovsky and Yunker, 1963) 


\section{Key to mites associated with bats in Egypt}

1. Tritosternum absent or present in a shape of tritosternal base remnant..... (Fig.1B); stigma dorsal (Fig. 1A).................................................Spinturnicidae Oudemans.....2

- $\quad$ Tritosternum well developed, with laciniae; stigma ventral......................(Fig. 2)

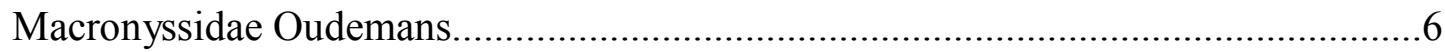

2. Claws I not enlarged; caruncles I developed...........................................................

- $\quad$ Claws I greatly enlarged; caruncles I rudimentary/reduced Ancystropus Kolenati..

3. Tritosternum represented by tritosternal base remnant

Meristaspis Kolenati 4

- $\quad$ Tritosternum absent (Fig. 3). Paraperiglischrus rhinolophinus C.L. Koch

4. Female idiosoma with a transverse line, a pair of setae immediately behind dorsal shield (Fig. 4). M. lateralis Kolenati

- $\quad$ Female idiosoma without such transverse line or pair of setae.

M. kenyaensis (Radford)

5. Short, stout, pointed, anteroventral seta on tarsus I of female proximal to anteroven tral process; sternal shield of female slightly wider than long, subquadrate (Fig. 6); tritosternum of male about four times as wide as long.... A. aethiopicus Hirst

- Short, broad, anteroventral, rodlike seta on tarsus I of female proximal to antero ventral process; sternal shield of female almost twice as wide as long, suboval (Fig. 7); tritosternum of male about five times as wide as long. A. zeleborii Kolenati

6. First pair of sternal setae slightly shorter than third pair (st1:st3 $=45-50: 56-60)$ (Fig. $8)$ Steatonyssus longipes Radovsky and Yunker

- $\quad$ First pair of sternal setae greatly shorter than third pair (st1:st3 = 1:3)

S. murinus (Lucas) 